\title{
Penile fracture: added value of novel assessment with contrast-enhanced ultrasound
}

\author{
Andrew Panayiotou, ${ }^{\oplus 1}$ Dean Y Huang, ${ }^{\oplus 1}$ Jonathan K Makanjuola, ${ }^{2}$ Paul S Sidhu ${ }^{\oplus}$
}

'Radiology, King's College Hospital, London, UK 2Urology, King's College Hospital, London, UK

Correspondence to Dr Andrew Panayiotou, a.panayiotou@nhs.net

Accepted 3 July 2019

\section{DESCRIPTION}

A 43-year-old man presented with blunt trauma to the penis during sexual intercourse when he felt a snap, instant pain and rapid detumescence and swelling. On examination, there was a visible haematoma and swelling at the dorsum of his penis. There was no blood in the meatus and he was able to pass urine. Given the typical history and physical examination findings, the diagnosis of a penile fracture was made and a confirmatory ultrasound (US) examination was performed.

Grey-scale US demonstrated a focal outpouching with mixed echogenicity extending from the left lateral aspect of the left corpus cavernosum, at the level of penile-scrotal junction (figure 1). An adjunct contrast-enhanced ultrasound (CEUS) was performed, which demonstrated active extravasation spreading from the site of rupture of the tunica. The extent of the haematoma, which is shown as a non-enhancing area, was clearly demarcated. CEUS also confirmed the viability of the corpus cavernosa, which enhanced normally, with no herniation of cavernosal tissue beyond the defect (figure 2). The site of the defect was marked on the skin at the time of US examination. In theatre, a small targeted left paramedian vertical incision was made over the site marked. A $1 \mathrm{~cm}$ defect was found on the left lateral corpora distal to the penoscrotal junction. The haematoma was evacuated and the defect in the tunica albuginea was closed.

Penile fracture, a result of rupture of the cavernosal tunica albuginea, is uncommon. In penile fracture, acute surgical intervention with the closure of the tunica albuginea is

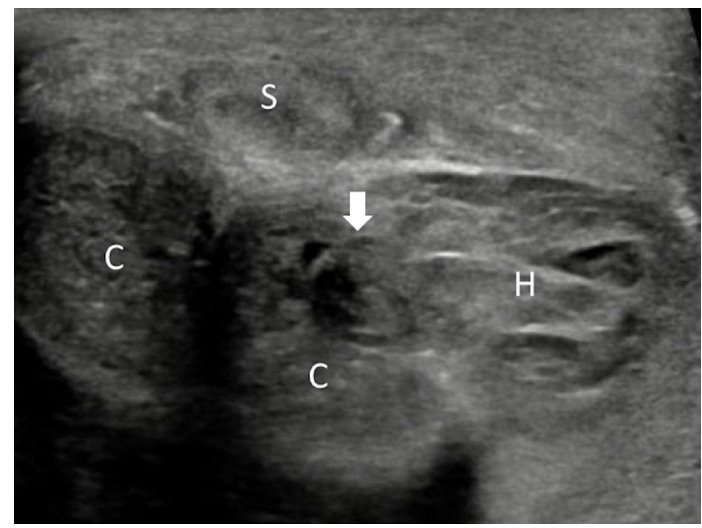

Figure 1 Grey-scale US figure of the fractured penis: corpora cavernosum (C); corpora spongiosum (S); fracture site (block arrow) and haematoma (H). US demonstrated a fracture to the left ventrolateral corpus cavernosum with associated haematoma. US, ultrasound.

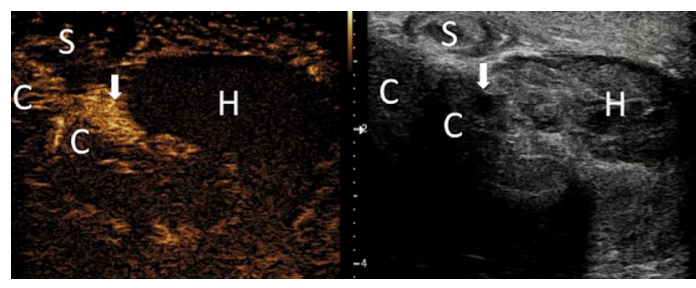

Figure 2 Figures from CEUS examination (split view: CEUS figure on the left and the corresponding grey-scale US figure on the right) of the penis: corpora cavernosum (C); corpora spongiosum (S); fracture site (block arrow) and haematoma $(\mathrm{H})$. Active contrast extravasation is shown at the fracture site (block arrow) at the left corpus cavernosum. The extent of the haematoma is clearly depicted as the non-enhancing area $(\mathrm{H})$ on CEUS. CEUS, contrast-enhanced ultrasound; US, ultrasound.

recommended as delayed diagnosis and treatment can lead to erectile dysfunction and penile curvature. ${ }^{1}$ US is easily accessible and is often the primary imaging modality used to delineate the extent of penile fracture. CEUS improves imaging of both macro- and micro-vasculature. ${ }^{2}$ Used as an adjunct, CEUS may improve accuracy in locating

\section{Patient's perspective}

I was first told by the surgeons that they might have to make a big cut to find and fix the break in my penis. Therefore, I am extremely grateful that the radiologist was able to pinpoint the break with the ultrasound machine so that the surgeons could fix it without doing major surgery. I was able to go home the next day.

\section{Learning points}

- In penile fracture, acute surgical intervention with the closure of the tunica albuginea is recommended as delayed diagnosis and treatment can lead to erectile dysfunction and penile curvature.

- Used as an adjunct, contrastenhanced ultrasound may offer added value in evaluating the rupture site in the tunica albuginea, haematoma size and the herniation of the corpus cavernosum.

- Improved preoperative evaluation of the penile fracture may allow for a targeted, minimally invasive surgical repair to be performed. 
the fracture with demonstration of site of extravasation. The size of any haematoma could be more precisely delineated on CEUS. Furthermore, CEUS could be useful in differentiating between any herniated cavernosal tissue and haematoma. ${ }^{2}$ Improved preoperative evaluation of the penile fracture could offer benefit for surgical planning and may allow for a targeted, minimally invasive repair, as opposed to a degloving explorative surgery, to be performed.

Contributors AP: drafting the article. DYH: conception and critical revision of the article. JKM and PSS: critical revision of the article. All authors were involved in the final approval of the version to be published.
Funding The authors have not declared a specific grant for this research from any funding agency in the public, commercial or not-for-profit sectors.

Competing interests None declared.

Patient consent for publication Obtained.

Provenance and peer review Not commissioned; externally peer reviewed.

\section{REFERENCES}

1 Nicola R, Carson N, Dogra VS. Imaging of traumatic injuries to the scrotum and penis. AJR Am J Roentgenol 2014;202:W512-20.

2 Sidhu PS, Cantisani V, Dietrich CF, et al. The EFSUMB guidelines and recommendations for the clinical practice of contrast-enhanced ultrasound (CEUS) in non-hepatic applications: update 2017 (long version). Ultraschall Med 2018;39:e2-44.

Copyright 2019 BMJ Publishing Group. All rights reserved. For permission to reuse any of this content visit

https://www.bmj.com/company/products-services/rights-and-licensing/permissions/

BMJ Case Report Fellows may re-use this article for personal use and teaching without any further permission.

Become a Fellow of BMJ Case Reports today and you can:

- Submit as many cases as you like

- Enjoy fast sympathetic peer review and rapid publication of accepted articles

- Access all the published articles

Re-use any of the published material for personal use and teaching without further permission

Customer Service

If you have any further queries about your subscription, please contact our customer services team on +44 (0) 2071111105 or via email at support@bmj.com.

Visit casereports.bmj.com for more articles like this and to become a Fellow 